\title{
Mango Seed Weevil, Sternochetus mangiferae (Fabricius) (Insecta: Coleoptera: Curculionidae) ${ }^{1}$
}

Robert E. Woodruff and Thomas R. Fasulo²

\section{Introduction}

The mango seed weevil, Sternochetus mangiferae (Fabricius), is not found Florida, but its presence in the major mango producing areas of the world indicates that it is a potential pest here. It is spread mainly by transportation of infested fruits since the weevil develops within the mango seed and can therefore be transported unnoticed from one locality to another (World Agroforestry Center 2003).

\section{Synonymy}

The generic name used in much of the older literature is Cryptorhynchus, but Buchanan (1939) designated $C$. mangiferae $\mathrm{F}$. as the genotype of Sternochetus Pierce. Warner (1956) used Sternochetus as the genus.

\section{Distribution}

This beetle is found in almost all of the major mango producing areas of the world: Australasia (but not Western Australia - personal communication, 
reddish to greyish with variable light markings as shown. Where it occurs in Australia, adult weevils are dark brown to black with grey markings (Pinese and Holmes 2005). Specimens can be readily sexed; the female has an elevated ridge at the pygidial (tergum of the last visible segment of the abdomen) apex which is merely rounded in the male.

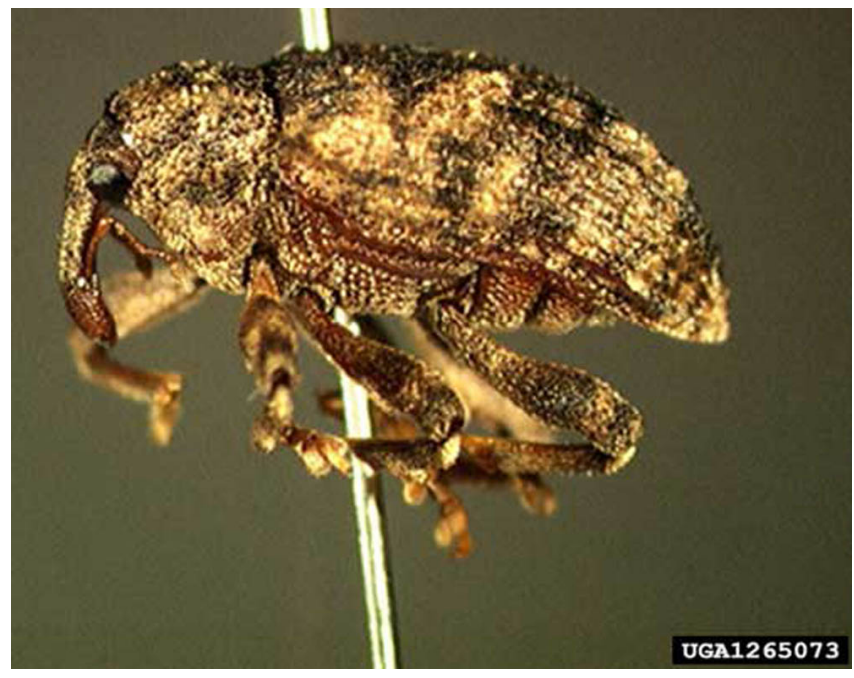

Figure 1. Adult mango seed weevil, Sternochetus mangiferae (Fabricius). Credits: Anson Eaglin, USDA-APHIS; www.invasive.org

While adults can fly they are not strong fliers and do not move far from the tree where the fruit drops. Evidence suggests that weevils infest new areas through the movement of infested fruit for propagation and consumption (Pinese and Holmes 2005).

Egg: The elongated and creamy white egg is covered by a protective brown covering with two tiny tails at one end (Pinese and Holmes 2005).

Larva: The newly emerged larva is an elongated, slender grub, white and legless. As such, it does not resemble a typical weevil larva. However, older instars have a more common weevil larval appearance in that they are compact and C-shaped (Pinese and Holmes 2005).

\section{Biology}

The literature on this species is contradictory on several aspects of its biology, possibly due to confusion with two other similar species. The following account is drawn primarily from a study done in Hawaii by Balock and Kozuma (1964) where only S. mangiferae occurs.

Eggs are laid singly on all areas of half mature (green) to ripe mango fruit in an incision made by the adult female Oviposition has been noted in the laboratory in subdued light in early morning and in early evening after dusk. The female covers each egg with a brown exudate and then cuts a crescent shaped area $(1 / 4$ to $1 / 2 \mathrm{~mm})$ in the fruit near the posterior end of the egg. The wound creates a sap flow, which solidifies and covers the egg with a protective opaque coating. Eggs hatch in from five to seven days, partly dependent on temperature. One female may lay 15 eggs per day, with a maximum of 300 over a three month period.

The newly hatched larva is about $1 \mathrm{~mm}$ long and burrows through the pulp and into the seed where it will remain until it becomes an adult.. Minimum time from hatching to seed penetration is one day. There are at least five larval instars in Hawaii. Larvae can penetrate the seed coat easier on younger fruit of all varieties, and apparently find entry impossible on mature seed of some varieties (e.g., Itamaraca). As the fruits mature, the tunnels are eliminated and it is not possible to distinguish between infested and non-infested seeds, unless they are cut open (Pertanian 2004).

Pupation usually occurs within the seed, although this sometimes happens in the flesh (Balock 1961). Duration of the pupal stage is about seven days. Newly formed pupae are nearly white, but change to a very light red shortly before the adult ecloses.

Often only one adult will mature in each seed, but as many as six have rarely been recorded. The weevils are nocturnal, but have only infrequently been collected singly in ultraviolet light traps. Flight has not been observed, but well developed wings are present, and specimens have been taken in invaginated (McPhail) fruit fly traps. When disturbed they drop to the ground and remain motionless. Adults hibernate by the hundreds during non-fruiting periods. In Hawaii, there appears to be a pre-oviposition diapause for adults emerging in May, or later, which is broken about the first of the year (coinciding with onset of regular mango fruiting). 
Onset of diapause seems to be associated with long-day photoperiod, and the break with short-day photoperiod (Balock and Kozuma 1964).

The time from egg to adult takes five to eight weeks and only one generation is produced each year. Weevils overwinter under loose bark around the base of mango trees or in the forks of branches. They can also live in leaf litter around the tree and approximately $25 \%$ of the adults over-winter in the seed. Adult weevils can live for two years, so even with a crop failure in one season some weevils can survive into the following year (Pinese and Holmes 2005).

\section{Hosts}

This species has not been reported developing in any host except mango, Mangifera indica $\mathrm{L}$. In the laboratory, oviposition has been obtained on potatoes, peach, litchi, plum, string beans, and several varieties of apple. However, none of the resulting larvae reached maturity.

\section{Survey and Detection}

This weevil is intercepted in Puerto Rico and the U.S. Virgin Islands, and occasionally at mainland U.S. ports from fruit shipments and tourists returning from the Caribbean Basin .

It is impractical to distinguish between infested and uninfested seeds unless they are cut open. As infected fruit is often not visibly damaged, a seed-splitting device is required for detection. Any seed suspected of infestation should be examined with a hand lens after splitting (NAPPO 2006).

\section{Management}

Many other mango-producing countries list this species as a "dangerous quarantine pest." Some offer recommended cultural and pesticidal management recommendations (Pertanian 2004, World Agroforestry Center 2003, Pinese and Holmes 2005).

The mango seed weevil is a quarantine pest for CPPC, IAPSC, NAPPO and OIRSA (NAPPO 2006).

\section{Selected References}

Balock JW. 1969. Notes and exhibitions. Proceedings of the Hawaiian Entomological Society 17: 327 .

Balock JW, Kozuma TT. 1964. Notes on the biology and economic importance of the mango weevil Sternochetus mangiferae (Fabricius), in Hawaii (Coleoptera: Curculionidae). Proceedings of the Hawaiian Entomological Society 18: 353-364.

Berger EW. 1912. Additional rules and regulations and modifications adopted by the board of control. University of Florida, University Record (Extra) 7: 1-15 (also Circular No. 3 Office of Inspector of Nursery Stock).

Berger EW. 1912. State nursery inspection law of Florida. Florida Department of Agriculture Quarterly Bulletin 22: 37-46.

Buchanan LL. 1939. Changes of names in Carabidae and Rhynchophora (Coleoptera). Proceedings of the Entomological Society of Washington 41: 79-82.

Chandler LR et al. 1996. Distribution and infestation levels of mango seed weevil in Barbados with an assessment of its economic impact between 1986 and 1991. Proceedings of the 31st. Annual Meeting [of the Caribbean Food Crops Society]. Kingshill, St. Croix (US Virgin Islands): Caribbean Food Crops Society. p. 324-332.

Commonwealth Institute of Entomology. 1964. Sternochetus mangiferae (F.). Distribution map of insect pests, Ser. A., Map No. 180.

Dammerman KW. 1929. Agricultural zoology of the Malay archipelago. J.H. Bussy, Ltd. Amsterdam. $473 \mathrm{p}$.

Ebeling W. 1959. Subtropical Fruit Pests. University of California, Berkeley. 436 p.

EPPO/CABI. 1997. Sternochetus mangifera. In Quarantine pests for Europe, 2nd edition. (Smith IM, McNamara DG, Scott PR, Holderness M. eds.). CAB International Wallingford, UK 
Fletcher TB. 1914. Some South Indian Insects and Other Animals of Importance Considered Especially from an Economic Point of View. Government Press, Madras, India. 565 p.

Fletcher T. (Ed.). 1917. Cryptorhynchtus mangiferae. In Report of the 2nd Entomological Meeting held at Pusa on the 5th to 12th February 1917. Calcutta, Supt. Govt. Printing. 340 p.

Follett PA, Gabbard Z. (1998). Questioning the pest and quarantine status of the mango seed weevil in Hawaii. http://www.epa.gov/ozone/mbr/ airc/1998/052peter.pdf (11 May 2006).

Follett PA. 2002. Mango seed weevil (Coleoptera: Curculionidae) and premature fruit drop in mangoes. Journal of Economic Entomology 95: $336-9$

Higgins JE. 1906. The mango in Hawaii. Hawaii Agricultural Experiment Station Bulletin 12: 1-32.

Holdaway FG, Jensen DD, Nishida T, Tanada Y. 1947. Miscellaneous insect problems. Hawaiian Agricultural Experiment Station Biannual Report for 1944-46: 77-79.

Howard LO. Report of the entomologist for 1911. USDA, Report of Entomology 1911: 1-42.

IATCP. Mango Seed Weevil (Sternochetus mangiferae). UF/IFAS International Agricultural Trade And Policy Center. http://fred.ifas.ufl.edu/ iatpc/tstar_puertoricomango.php (11 May 2006).

Jarvis H. 1946. Pests of mango. Queensland Agricultural Journal 62: 10-14.

Jacobsen WC. 1928. Bureau of Plant Quarantine and Pest Control. California Department of Agriculture Monthly Bulletin 17: 653-704.

Keiser I. 1959. Observations on mango weevil infestations in 1957. Proceedings of the Hawaiian Entomological Society 17: 83-84.

Kissinger DG. 1964. Curculionidae of America North of Mexico; a Key to the Genera. Taxonomic Publications, So. Lancaster, Mass. 143 p.
Lefroy H,. Howlett FM. 1909. Indian Insect Life. Thacker, Spink \& Co., Calcutta. 839 p.

McBride OC, Mason AC. 1934. The effects of subfreezing temperatures on the mango weevil. Journal of Economic Entomology 27: 902-907.

Marlatt CL. 1911. The mango weevil (Cryptorhynchus mangifera Fab.). USDA, Bureau of Entomology Circular 141: 1-3.

Moznette GF. 1922. Insects injurious to the mango in Florida and how to combat them. USDA, Farm Bulletin 1257: 1-22.

NAPPO. (2006). Sternochetus mangiferae (F.), Emerging pest in the Caribbean Basin. NAPPO Phytosanitary Alert System. http://www.pestalert. org/viewArchPestAlert.cfm?rid=3 (11 May 2006).

Nishida T. 1955. The phenomenon of arrested insect development in the Hawaiian Islands. Proceedings of the Hawaiian Entomological Society 15: 575-582.

Pertanian J. (2004). Mango Seed Weevil. PQNet. http://agrolink.moa.my/pqnet/msw/bi/ index.html (10 May 2006)

Pinese B, Holmes R. (2005). Managing mango seed weevil. DPI\&F Notes. (11 May 2006).

Pope WT. 1929. Mango culture in Hawaii. Hawaii Agricultural Experiment Station Bulletin 58: 1-27.

Pierce WD. 1917. A Manual of Dangerous Insects Likely to be Introduced in the United States Through Importations. USDA Bureau of Entomology, Washington, DC. 256 p.

Ramakrishna, A.T.V. 1923. Some insects noted as pests of fruit trees in south India. Agricultural Journal of India18: 50-59.

Subramanyam CK. 1926. A note on the life history of Cryptorhynchus mangiferae (Fab.). Madras Agriculture Department Yearbook for 1925: 29-36.

Szito A. Re: UF/IFAS Pest Alert - mango seed weevil. Department of Agriculture and Food Western Australia.aszito@agric.wa.gov.au (26 May 2006). 
Tanada Y. 1951. Possible association of mango weevil infestation with premature fruit drop in mangoes. Hawaiian Agricultural Experiment Station Biannual Report for 1948-50: 71-72.

Van Dine DL. 1906. The mango weevil (Cryptorhynchus mangiferae Fabr.). Hawaii Agricultural Experiment Station Bulletin 17: 1-11.

Warner RE. 1956. Nomenclature of Sternochetus mangiferae (F.), the mango weevil (Coleoptera, Curculionidae). Entomology News 67: 246-247.

Williams, F.X. 1946. Cryptorhynchus

mangiferae (Fabr.). Proceedings of the Hawaiian Entomological Society 12: 479.

World Agroforestry Center. (2003). Mango Seed Weevil. Mango Growing in Kenya. http://www. knowledgebank.irri.org/cglrc/icraf/mangoBook/ Pests_and_Diseases/Mango_Seed_Weevil.htm (11 May 2006).

Yee W. 1958. The mango in Hawaii. University of Hawaii Agricultural Extension Circular 388: 1-26. 